\title{
THE IMPACT OF THE PRO AND CONS POLICIES IN JOKOWI ERA'S ON THE MACRO ECONOMY OF SOCIETY
}

\author{
Akhmad Kusuma Wardhana \\ Departemen Sains Ekonomi Islam, Universitas Airlangga, Indonesia \\ Email: akhmadkusumaw@gmail.com
}

\section{ARTICLE HISTORY}

Received:

16 June 2021

Revised:

12 October 2021

Accepted:

08 November 2021

Online available:

20 November 2021

Keywords:

Corona, social restriction

policy, Jokowi, macro

economy

*Correspondence:

Name: akhmad kusuma

wardhana

E-mail:

akhmadkusumaw@gmail.com

\section{ABSTRACT}

Introduction: Corona is a new variant of the virus that spreads very quickly. It is only by physical contact the virus capable on infecting human body as its host. Governments in various countries have implemented social restrictions or lockdowns to reduce the spread of the virus.

Methods This study uses descriptive analysis method. The sample of this study is Jokowi's three policies on handling corona.

Results: Not all of the policies contrary considered for the public are detrimental. The lack of a lockdown from the start was due to save foreign exchange from the tourism sector before the lockdown occurred.

Conclusion and suggestion: The social restriction policy has not only resulted in positive way for the medical community, but also negative way with the decline of the national economy.

\section{INTRODUCTION}

The corona virus has haunted society for almost a year, starting from the imposition of large-scale social restrictions on March 11, 2020, until today. This is done to avoid the chain of virus spread (Setiati and Azwar 2020), also to avoid a drastic increase of positive numbers in the community (Riadil 2020). The central and local governments also apply curfew rules, which people are prohibited from gathering in public places. Therefore, municipal governments in various cities conduct raids on places that have the potential to cause crowds (Mustafa, Abdullah, and Jayus, n.d.).

The health protocol can indeed prevent the spread of the virus, but it will also have a major impact on the national economy (Qarnain, Muthuvel, and Bathrinath 
2020). Social restrictions cause shopping centers to decrease their income. In addition, many MSMEs (Micro, Small, and Medium Entreprises) have been forced to close their businesses due to declining incomes, so they are unable to pay their employees. The immediate consequences can be seen, where massive layoffs took place in a forced manner (Megatsari et al. 2020).

The Indonesian economy, like all economies around the world, is suddenly in a precarious position. Even due to the COVID-19 pandemic, GDP growth will clearly stall. Not to mention the problem of the increasing number of unemployed due to unilateral layoffs. Not only the local sector, the export-import sector is also constrained, where Indonesian manufacturers will be very weak on distributing their products due to the declining of global market demand (Engkus et al. 2020).

The Indonesian government through Jokowi's presidential cabinet has implemented health protocols and several policies related to handling the corona pandemic. However, not all of the policies received a positive reaction from the public. Of course, there are pros and cons to the public's views on this policy. This study aims to analyze the impact of Jokowi's pro and contra policies on the macro economy in Indonesia.

\section{LITERATURE REVIEW}

The world has indeed been in chaos since social restrictions were imposed. However, this is not only in the interests of medical personnel, but also to avoid casualties. As of February 2021, the number of deaths due to corona worldwide has reached more than 2.4 million. Indonesia itself is not better off than other countries, because the death toll has reached more than 33.000 people (Nag and Puniani 2021).

One of the reasons why many countries have imposed lockdowns is due to the characteristics of the SARS-CoV 2 virus, which has a thorny surface and easy to stick into the human body as its host (Djalante et al. 2020). Moreover, because this virus is an RNA type, it will easily mutate, so it will create new variants that make it more difficult for health experts to predict the characteristics of the virus, as well as to design vaccine prototypes. Corona virus can be easily transmitted only by physical contact or by spraying liquid particles that are spread through the mouth and nose (McGonagle et al. 2020).

Cases of COVID-19 were reported in at least 214 countries. Many governments in each country impose strict restrictions on physical activities such as holidays for companies and agencies, implement a work from home system, lock down areas that are prone to high pandemics, and wear masks outside the home (Bender 2020). Lockdown periods are different in each country, and not all countries implement a lockdown. Cases such as in Indonesia implementing the PSBB policy still allows vital economic sectors to continue operating (Fealy 2020). 
The impact of large-scale lockdowns and restrictions is not entirely bad. Chakraborty and Maity in their study stated that lockdowns and social restrictions have a positive effect on the environment of a country (Chakraborty and Maity 2020). Lockdown indirectly has an impact on renewing environmental conditions (Qarnain, Muthuvel, and Bathrinath 2020), especially by factory closures and reducing the use of private vehicles and public transportation (Lahcen et al. 2020). COVID-19 is improving air quality in many parts of the world by the lockdowns imposed during the pandemic process (Caraka et al. 2020). In addition, lockdowns can reduce the impact of pollution and environmental damage due to project exploitation on manufacturing activities (Rizou et al. 2020), as well as a reduction in the total manufacturing of waste disposed (Masrur et al. 2020).

\section{RESEARCH METHODS}

This study uses a qualitative method with a case study approach. This study uses 3 government policies throughout 2020 in dealing with pandemics in Indonesia as research samples. This study describes the sample using a descriptive analysis approach. Data is also taken from bps.go.id as an illustration to support the existing data findings.

\section{RESULT AND ANALYSIS}

\section{The Distrust of Jokowi's Cabinet on Corona}

When the corona virus began to spread globally, the Indonesian government actually opened access for foreigners as much as possible in order to increase the country's foreign exchange through tourism. In addition, the government's denial from January to early March about the existence of the corona virus further added to the public perception that the corona virus was just a myth. Furthermore, the blow-ups from the media that kept reporting that the corona virus cannot survive in tropical countries with hot temperatures, further obscured the dangers of the corona virus, so there was no need for a lockdown.

Overseas health experts were concerned from the start that Indonesia tended to cover up facts about the transmission of the virus. One of the epidemiology professors from the Harvard TH Chan School of Public Health, Marc Lipsitch, said Indonesia might have missed the case of the corona virus disease. Local and international news portals even suspected that the lack of cases in Indonesia was due to inadequate testing and political intervention in reporting the spread of the corona to the public. According to The Jakarta Post on April 5, 2020, the central government had only conducted an average of 240 daily PCR tests since March 2.

Published by University of Airlangga.

This is an open access article under the CC BY SA license (https://creativecommons.org/licenses/by-sa/4.0/) 
A study by Harvard University public health academics in February 2020 found that Indonesia should have reported a coronavirus outbreak and could have undetected cases given its extensive air links to China and the city of Wuhan as the epicenter of the outbreak. But the Indonesian government's response had been quite the opposite, Indonesia has criticized a US study that questioned why the world's fourth most populous country had not recorded any cases of the coronavirus, calling the findings an insult and insisting that the country was on high alert.

Indonesian Health Minister Terawan Agus Putranto called the Harvard report "insulting" and said the country had the right testing equipment. Even more in denial, until early March, the government claimed there were no cases of infection, which Minister of Health Terawan Agus Putranto eccentrically linked the absence of positive cases of corona to the massive prayer and worship by Indonesians. In addition, the Minister of Home Affairs appealed to the public to eat more bean sprouts and broccoli, while President Joko Widodo (Jokowi) promoted traditional herbal medicine to overcome the corona virus. Several religious experts have also revealed the benefits of ablution water which can prevent on being exposed to the corona virus, so there is no need to impose a lockdown or social restrictions.

This was not entirely negative, but also had a positive impact on the Indonesian economy. At least Indonesia was still able to maintain the number of foreign tourists until the end of February 2020 at the point of 800.000 . This was enough to increase the country's foreign exchange as well as provision for tourism industry players for futurecapital.

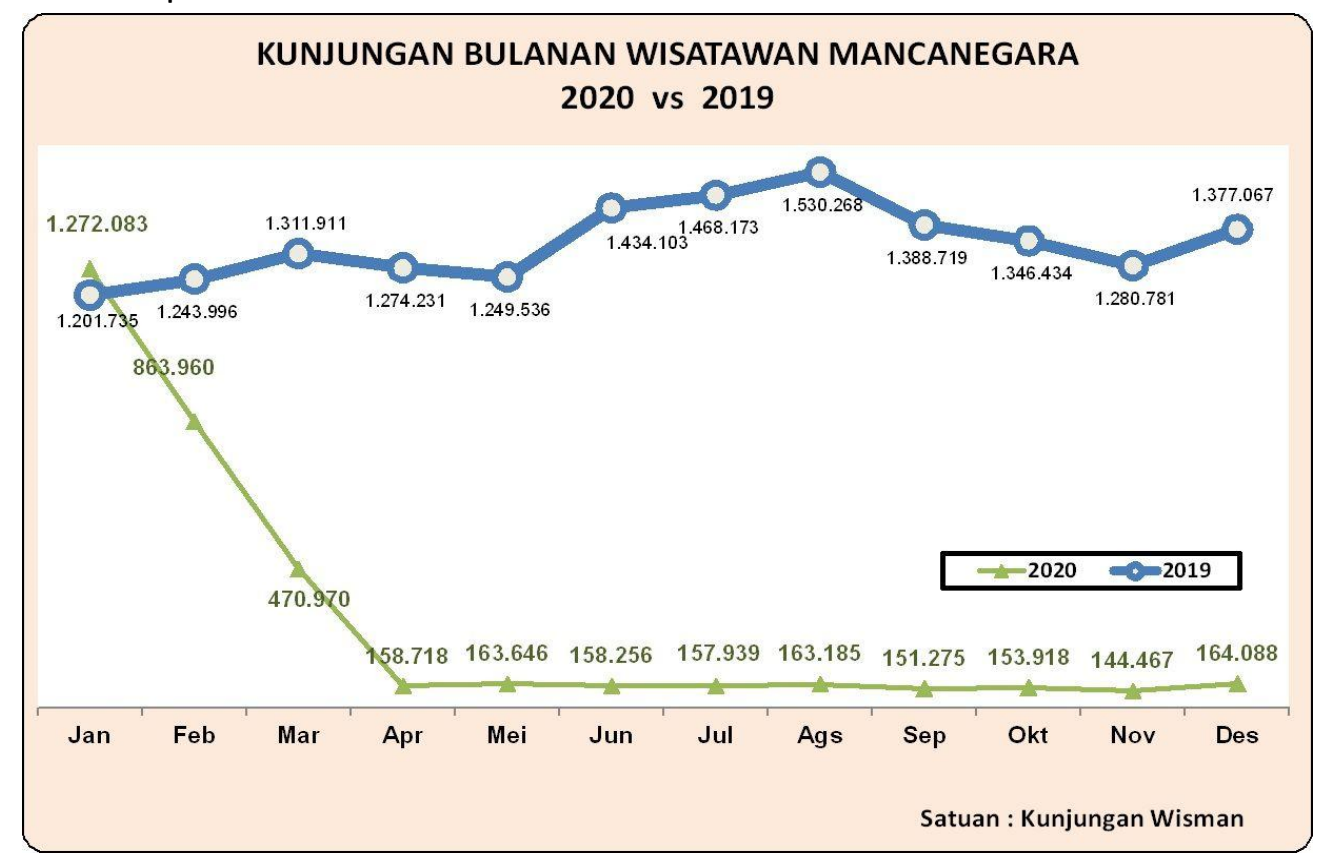

Source: kemenparekraf.go.id

Figure 1 


\section{Akhmad Kusuma Wardhana}

\section{Comparison of total 2019 and 2020 foreign tourists in Indonesia}

The picture above showed that in January the number of foreign tourists was still at a normal point, namely between 1.200 .000 , which was still a reasonable number to revive the tourism industry rapidly. In February, the number of tourists decreased, which was more than 300.000. However, this was not necessarily a negative thing (Judge 2020), because with such a large number, at least the tourism industry can still got optimal benefits (Prideaux, Thompson, and Pabel 2020). In March, the number of tourists decreased by half, and reached the peak of the decline in April, when the PSBB and the entry ban on foreign tourists began to take place (Guridno and Guridno 2020).

From the picture, it can be concluded that the government's policy to keep open entry visas for tourists was not entirely bad. It was conceivable that if the government unilaterally imposed a ban on foreign tourists entering in January, when the total level of tourists was still normal, perhaps the tourism industry would not have the stock at all to prepare for future income vacancies. Moreover, President Jokowi seems more concerned about the threat of the virus to trade, investment, and tourism (Fealy 2020). In February, when many countries imposed strict travel restrictions, he planned to offer discounts up to $30 \%$ to attract tourists. His government even allocated nearly $A \$ 8$ million to pay social media influencers for tourism promotion. This was done to save tourism foreign exchange as much as possible before social restrictions were really implemented (Riadil 2020).

\section{PSBB Enforcement in Lieu of Lockdown}

Indonesia has imposed large-scale social restrictions to deal with the spread of the corona virus, compared to a total lockdown as many countries have done. PSBB requires offices, schools, places of worship and public spaces to be closed. Local governments that enforce PSBB can limit transportation capacity within an area, but are not given the authority to close inter-regional transportation services. In the run-up to Ramadan and Eid al-Fitr, interregional travel is restricted under the national exodus ban and Ministry of Transportation regulations, with exceptions for distributors of basic goods and food supplies, as well as people with urgent interests (Djalante et al. 2020).

This policy is enforced not without reason. Increasing traffic and long queues at several public transportation hubs in Jakarta just a day after President Joko "Jokowi" Widodo's call to "work from home" to slow the rapid spread of the new coronavirus disease COVID-19, provided three clues (Suryahadi, Al Izzati, and Suryadarma 2020). First, many workers are unable to work from home because not all people are desk workers (Hakim 2020). Second, cmpany owners being confused because the closing of their place of business will automatically reduce income. This can affect the aggregate of their companies. Third, clearer emergency measures are needed to address impending

Published by University of Airlangga.

This is an open access article under the CC BY SA license (https://creativecommons.org/licenses/by-sa/4.0/) 
social inequality (Almuttaqi 2020). With 55 percent of the workforce in the informal sector, the reason is enough for the government not to impose a full lockdown. No work means no pay for the lower middle class. For most micro, small and medium enterprises (MSMEs), this means a severe shock to their business (Disemadi and Shaleh 2020).

This can be seen in several business owners who have not complied the policy during March to June, resulting in many people continuing to work using public transportation even though the city government has imposed passenger capacity restrictions. The Confederation of Indonesian Trade Unions (KSPI) recently stated that dozens of companies outside the sector are still granted operational permits (Salahudin et al. 2020). "The health and food product industry sector must be open to maintain the survival of the community. The DKI Jakarta Manpower, Transmigration and Energy Agency noted that around 200 large companies, including electronics manufacturers, has received permission from the Ministry of Industry to operate in Jakarta during the PSBB policy (Olivia, Gibson, and Nasrudin 2020).

According to a report by the World Bank Aspiring Indonesia, it is estimated that only one in five Indonesians are economically secure. Around 24.8 million Indonesians live under US\$1 per day, 9.22 percent of the population, and more than 60 million are vulnerable to falling into poverty due to the corona pandemic (Suryahadi, Al Izzati, and Suryadarma 2020). The banking sector also faces the risk of late loan payments by vulnerable individuals and MSMEs, reducing their NPL values to a critical point (Djalante et al. 2020).

It all started in March 2020 as an unforgettable month, or will even be remembered in the world history curriculum. The initial attack of COVID-19 led to a very rare situation, and even only a few decades apart, in which there was a complete loss of confidence in financial markets around the world. This can be compared to the situation of 'Black Monday' in 1987 and 'Great Crash' in 1929 (Lahcen et al. 2020).

With the impact of world financial markets, it will certainly affect the volatility of the dollar, so it will also affect the exchange rate of the dollar against the rupiah. The impact looks extraordinary, where at the end of March 2020 the dollar exchange rate against the rupiah just broke in the range of 16,000 and was getting closer to the value during the monetary crisis of the New Order era (Booth 2000). This is certainly a horror story in itself that can traumatize the Indonesian people, where at the time the country's monetary crisis was on the verge of collapse and sparked a civil war, massive demonstrations that led to chaos and looting, until it ended in a revolution to overthrow the legitimate government under Suharto (Manning). 1993). 
USD - 6 Bulan Terakhir - Rp. 14.011/USD

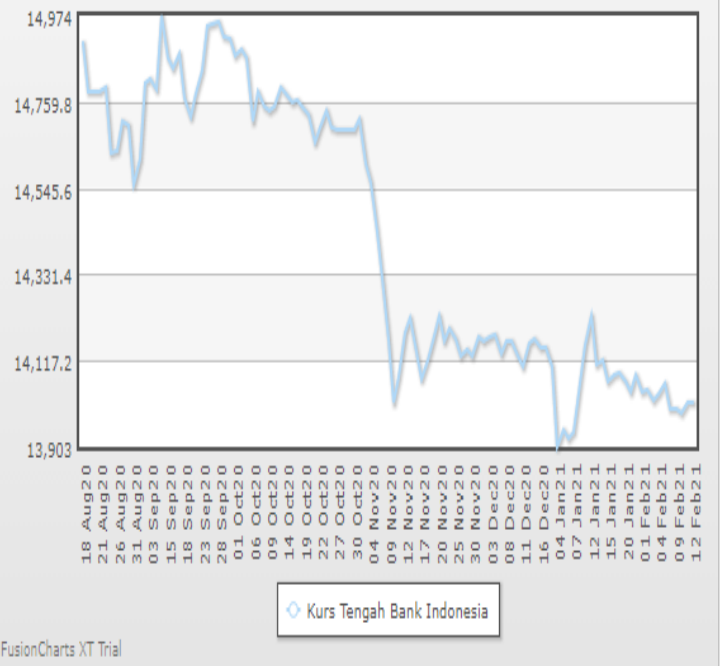

USD - 1 Tahun Terakhir - Rp. 14.011/USD

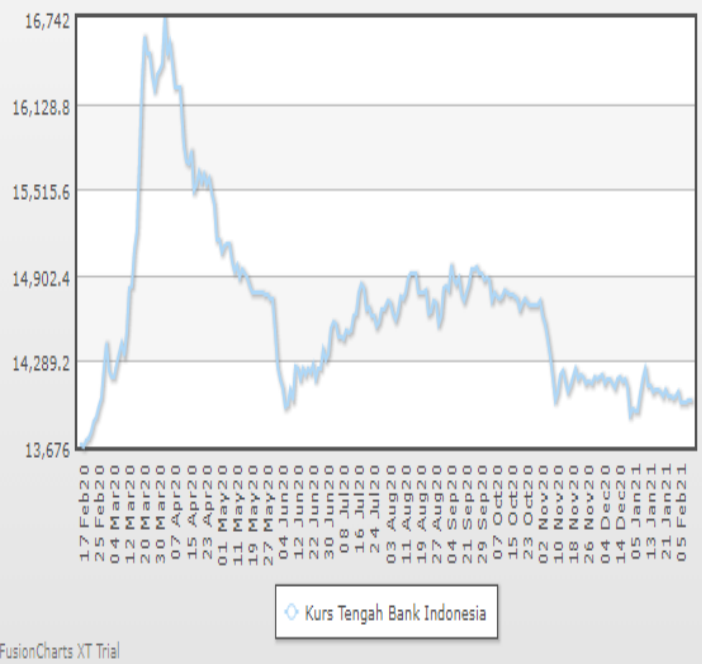

Source: kursdollar.org

Figure 2

Total USD exchange rate against rupiah in the last 1 year

In the table above, it can be seen that there is a very significant spike in the dollar exchange rate against the rupiah. Rupiah almost touched the figure of Rp. 17,000, which is in the range of $\mathrm{Rp} .16,742$, and that is not something encouraging. The beginning of the entry of corona and the imposition of social restrictions, the imposition of a curfew, a ban on traveling out of town. Travel tires abroad, orders for holidays to the all institutions and companies, as well as the implementation of work from home are the main factors of the sinking of the rupiah exchange rate throughout February to the end of March (Riadil 2020)t. It can be concluded that the policies taken by the government at the beginning of the pandemic hit the strength of the rupiah hardly. This can have an impact on inflation and a wider poverty gap in the community (Suryahadi, Al Izzati, and Suryadarma 2020).

High-income households are less affected than low-income households. In terms of location, PSBB has an impact on urban and sub-urban families in the rural nonagricultural sector (Subekti, Nurhaeni, and Hariyanti 2020). Increasingly, rural farming families are less affected by the PSBB policy (Megatsari et al. 2020), considering that their income comes mostly from the agricultural sector, which is exempt from PSBB restrictions. The agricultural sector, including the distribution of basic commodities, is exempted from PSBB in sending supplies of their agricultural products (Setiati and Azwar 2020). 
This is what causes a dilemma for the government on continuing to enforce the system of opening and closing social restrictions. The fact that business actors and the government must continue to prepare, coordinate and ensure the stability of basic needs such as rice, eggs, chicken, sugar, chili and shallots, further strengthens the policy. In addition, this policy can help banking operations to ensure minimal disruption to the flow of loans and investment in the real industrial sector, although the impact is not fully helpful (Gelgel, Apriani, and Ginting 2020).

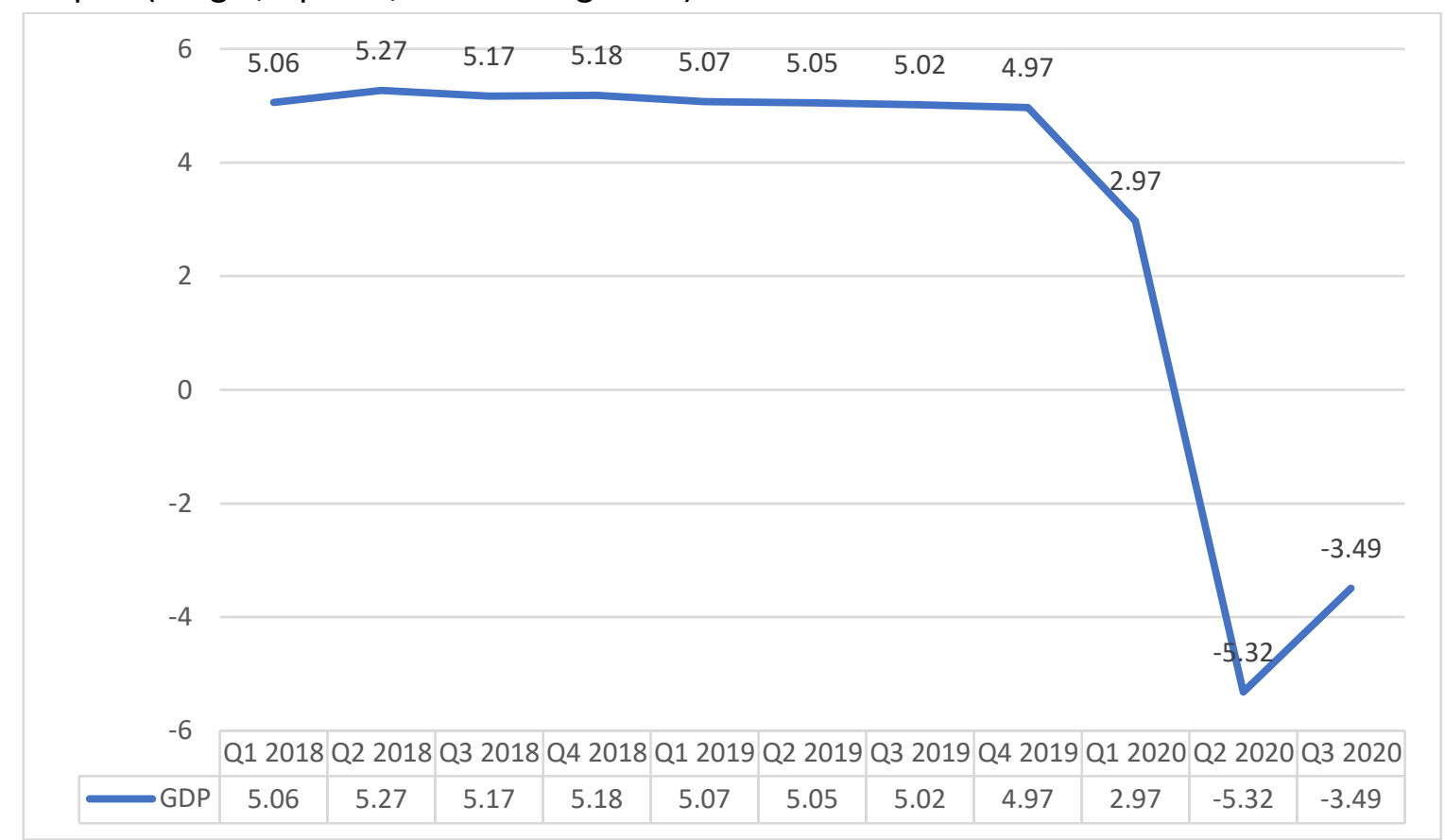

Source: bps.go.id

Figure 3

The Growth of Indonesia's GDP

The picture above showed that in the first quarter of 2020, namely at the beginning of the implementation of the PSBB opening and closing, there was still a GDP growth surplus although only half of the normal. From a political economy perspective, using a neo-classical approach, it can be concluded that to overcome weaknesses and imperfections, the government should intervene in the economic affairs of the Indonesian people (Bender 2020).

One of the policies apart from opening and closing the PSBB in terms of political economy is to cut the APBN and APBD (Judge 2020). APBN and APBD, which are not expenditure priorities, are allocated to each region to control the prices of basic goods, ensure the availability of basic commodities, in order to intensify the socialization of social restriction policies. This policy is considered the most effective on handling COVID19 in Indonesia compared to imposing a full lockdown system such as the European Union and the United States. The government seems to be implementing the policy 


\section{Akhmad Kusuma Wardhana}

gradually to avoid drastic economic impacts (Khasanah, Pramudibyanto, and Widuroyekti 2020).

\section{Simultaneous Pilkada Procurement}

Pilkada is indeed a democratic party event that must be held in Indonesia. What makes this 2020 Pilkada very special was that they have to be held in the midst of the COVID-19 pandemic. Therefore, health protocols must certainly be tightened, especially considering the number of new COVID-19 cases continues to grow in Indonesia at almost a record high. But in fact, holding simultaneous regional elections in December also contributed to positive cases of corona in Indonesia. The reason was that not all successful teams of regional head candidates complied the health protocols and avoided crowds (Fealy 2020).

One example was the holding of the Surabaya election, where both the candidate pair Machfud Arifin (MA) and Eri Cahyadi both violated health protocols. MA supporters violated protocol when crowding during the campaign with the slogan "destroy Risma". Meanwhile, the candidate pair Eri Cahyadi violated the crowding protocol when registering in KPU accompanied by PDIP cadres and their sympathizers (Subekti, Nurhaeni, and Hariyanti 2020).

The risk has prompted widespread calls for a postponement of the election, including from Nahdlatul Ulama and Muhammadiyah as the two largest Islamic organizations in Indonesia. They argued that democracy is expensive, but should it cost citizens' lives? Especially during a pandemic. However, President Jokowi denied that any further delay would deny the law of the constitutional rights and risked creating a power vacuum across the archipelago (Prabowo, Syafri, and Juanda 2020). The government has pledged 5.2 trillion rupiah ( $\$ 370$ million) for the implementation of health protocols during the election. These include measures to limit the number of voters at each polling station to a maximum of 500 , hourly regulated voter turnout, and a pre-set voting schedule (Gelgel, Apriani, and Ginting 2020).

This will have an impact on the national economy in the long term, where a surge in COVID-19 patients will continue to extend social restrictions. In addition, industry and manufacturing will remain inoperative. With the quarterly economy having reached minus in the third quarter with number 3.49 in figure 3, Indonesia will reach a long-term recession due to the continuous social restrictions (Megatsari et al. 2020).

In addition, the policy of holding elections in the midst of a pandemic will create public sentiment where the corona virus is considered as harmless, so that people should be free to move outside (Almuttaqi 2020). Concerns are growing as the Election Supervisory Body (Bawaslu) reported at least 243 health protocol violations during the registration stage for the election from September 4 to 6 , with many candidates brought 
crowds and entourages. Three commissioners of the General Elections Commission (KPU), including KPU chairman Arief Budiman, also tested positive for COVID-19 in the midst of election preparations (Rosanti 2020).

At least 5.1 million people were predicted to fall below the poverty line by the end of June 2020 due to COVID-19 in Indonesia. Unfortunately, requests for waivers can be exploited by candidates who use economic aid to gain voters (Gelgel, Apriani, and Ginting 2020). The last four months, starting from the PSBB period in March to June, have revealed to the public that the government was very unprepared to face disasters on a national scale, and especially those related to health. This can be seen from the confusion of the government in overcoming the pandemic, such as continuing to hold local elections (Suryahadi, Al Izzati, and Suryadarma 2020).

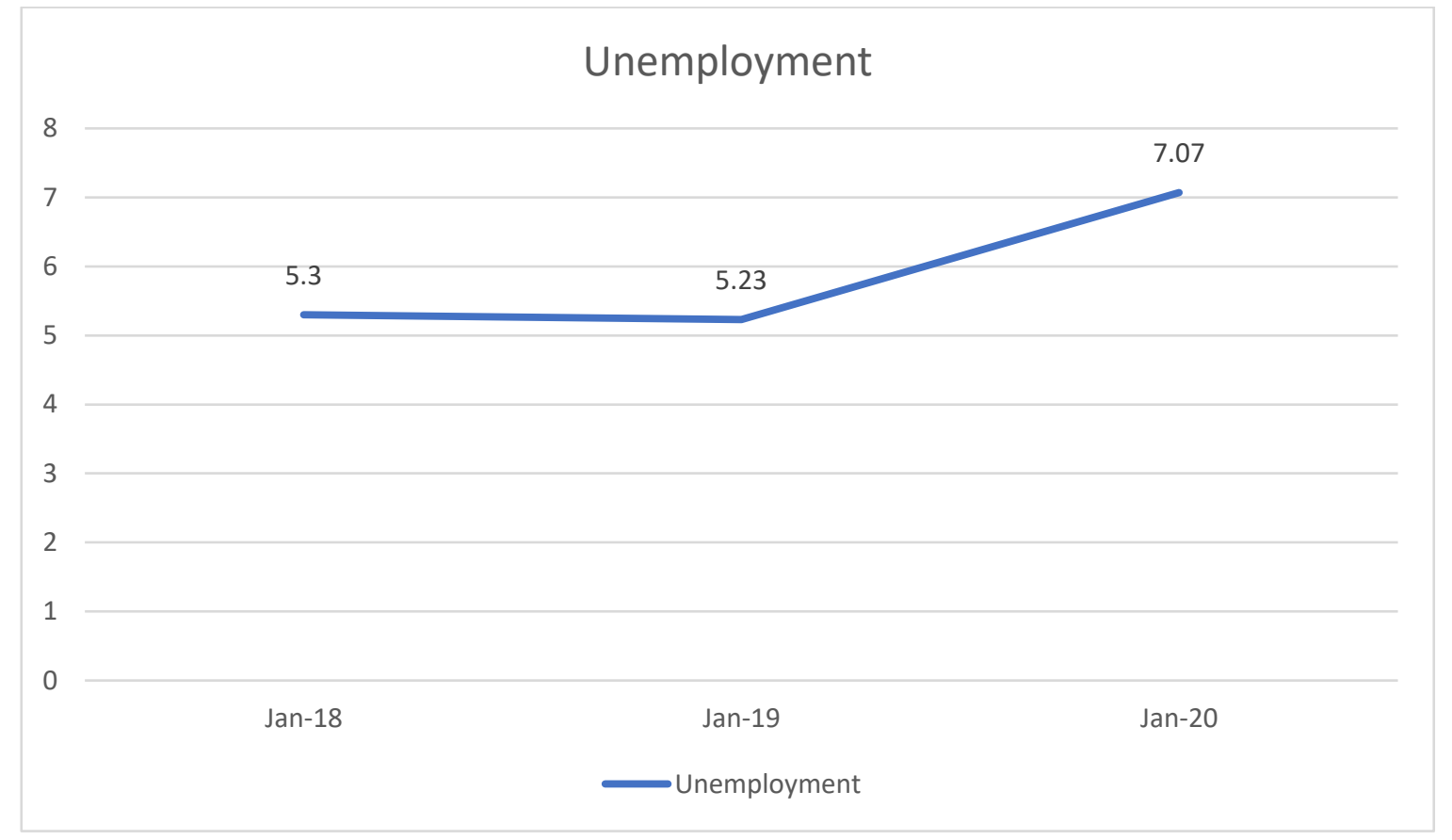

Source: bps.go.id

Figure 4

The impact of corona on the number of unemployed in Indonesia

The picture above showed that there is a significant increase in unemployment during the pandemic. This should be a reference for the government that the urgency of handling the corona is needed, one of which is to set a good example for the community. Unfortunately, political interests have removed the government's main priority in consistently implementing health protocols (Giri et al. 2020). With the increasing number of new positive cases, the longer the economic recovery process will have an impact on the continued increase in the unemployment rate (Setiati and Azwar 2020).

\section{CONCLUSION}


Government policies that often reap criticism from the public are not all detrimental. There are several considerations for implementing this policy. The PSBB policy as a substitute for the lockdown is implemented to maintain macroeconomic stability, while still allowing the public to carry out economic activities, but not on a full scale. In addition, the government's neglect of the initial spread of the corona virus was caused to save foreign exchange for the tourism industry, so to not completely lose the money in the first quarter of 2020. However, the policy of holding simultaneous regional elections is a bad thing because it is only to legalize political interests.

\section{REFERENCES}

Almuttaqi, A Ibrahim. 2020. "Kekacauan Respons Terhadap COVID-19 Di Indonesia." Thc Insigjts 13.

Bender, Lisa. 2020. "Interim Guidance for COVID-19 Prevention and Control in Schools." UNICEF. ERIC.

Booth, Anne. 2000. "Poverty and Inequality in the Soeharto Era: An Assessment." Bulletin of Indonesian Economic Studies 36 (1). Taylor \& Francis: 73-104.

Caraka, R E, Y Lee, R Kurniawan, R Herliansyah, P A Kaban, B I Nasution, P U Gio, R C Chen, T Toharudin, and B Pardamean. 2020. "Impact of COVID-19 Large Scale Restriction on Environment and Economy in Indonesia." Global Journal of Environmental Science and Management 6 (Special Issue (Covid-19)). GJESM Publisher: 65-84.

Chakraborty, Indranil, and Prasenjit Maity. 2020. "COVID-19 Outbreak: Migration, Effects on Society, Global Environment and Prevention." Science of the Total Environment 728. Elsevier: 138882.

Disemadi, Hari Sutra, and Ali Ismail Shaleh. 2020. "Banking Credit Restructuring Policy amid COVID-19 Pandemic in Indonesia." Jurnal Inovasi Ekonomi 5 (2).

Djalante, Riyanti, Jonatan Lassa, Davin Setiamarga, Choirul Mahfud, Aruminingsihm Sudjatma, Mochamad Indrawan, Budi Haryanto, Muhammad Sabaruddin Sinapoy, Irina Rafliana, and Susanti Djalante. 2020. "Review and Analysis of Current Responses to COVID-19 in Indonesia: Period of January to March 2020." Progress in Disaster Science. Elsevier, 100091.

Engkus, Engkus, Nanang Suparman, Fadjar Tri Sakti, and Husen Saeful Anwar. 2020. "Covid-19: Kebijakan Mitigasi Penyebaran Dan Dampak Sosial Ekonomi Di Indonesia." LP2M.

Fealy, Greg. 2020. "Jokowi in the Covid-19 Era: Repressive Pluralism, Dynasticism and the Overbearing State." Bulletin of Indonesian Economic Studies 56 (3). Taylor \& Francis: 301-23. 
Gelgel, Ni Made Ras Amanda, Kadek Dwita Apriani, and Richard T Ginting. 2020. "Communication Strategies in the 2020 Local Election Stages Socialization During the Covid-19 Pandemic." Jurnal Komunikasi Ikatan Sarjana Komunikasi Indonesia 5 (2): 205-16.

Giri, Rajanish, Taniya Bhardwaj, Meenakshi Shegane, Bhuvaneshwari R Gehi, Prateek Kumar, Kundlik Gadhave, Christopher J Oldfield, and Vladimir N Uversky. 2020. "Understanding COVID-19 via Comparative Analysis of Dark Proteomes of SARSCoV-2, Human SARS and Bat SARS-like Coronaviruses." Cellular and Molecular Life Sciences. Springer, 1-34.

Guridno, Eddy, and Aberar Guridno. 2020. "Covid-19 Impact: Indonesia Tourism in New Normal Era." Int. J. Manag. Humanit 4 (11): 31-34.

Hakim, Luchman. 2020. "COVID-19, Tourism, and Small Islands in Indonesia: Protecting Fragile Communities in the Global Coronavirus Pandemic." Journal of Marine and Island Cultures, v9n1, 130-41.

Khasanah, Dian Ratu Ayu Uswatun, Hascaryo Pramudibyanto, and Barokah Widuroyekti. 2020. “Pendidikan Dalam Masa Pandemi Covid-19." Jurnal Sinestesia 10 (1): 4148.

Lahcen, B, J Brusselaers, K Vrancken, Y Dams, C Da Silva Paes, J Eyckmans, and S Rousseau. 2020. "Green Recovery Policies for the COVID-19 Crisis: Modelling the Impact on the Economy and Greenhouse Gas Emissions." Environmental and Resource Economics 76 (4). Springer: 731-50.

Manning, Chris. 1993. "Structural Change and Industrial Relations During the Soeharto Period an Approaching Crisis?" Bulletin of Indonesian Economic Studies 29 (2). Taylor \& Francis: 59-95.

Masrur, Arif, Manzhu Yu, Wei Luo, and Ashraf Dewan. 2020. "Space-Time Patterns, Change, and Propagation of COVID-19 Risk Relative to the Intervention Scenarios in Bangladesh." International Journal of Environmental Research and Public Health 17 (16). Multidisciplinary Digital Publishing Institute: 5911.

McGonagle, Dennis, James S O’Donnell, Kassem Sharif, Paul Emery, and Charles Bridgewood. 2020. "Immune Mechanisms of Pulmonary Intravascular Coagulopathy in COVID-19 Pneumonia." The Lancet Rheumatology. Elsevier.

Megatsari, Hario, Agung Dwi Laksono, Mursyidul Ibad, Yeni Tri Herwanto, Kinanty Putri Sarweni, Rachmad Ardiansyah Pua Geno, and Estiningtyas Nugraheni. 2020. "The Community Psychosocial Burden during the COVID-19 Pandemic in Indonesia." Heliyon 6 (10). Elsevier: e05136.

Mustafa, Mustafa, Assyari Abdullah, and Jayus Jayus. n.d. "ANALISIS STRATEGI PEMULIHAN CITRA JOKOWI DALAM MENGATASI WABAH COVID-19 DI 
INDONESIA." Jurnal IImu Komunikasi UHO: Jurnal Penelitian Kajian IImu Komunikasi Dan Informasi 6 (1): 77-97.

Nag, Biswajit, and Ashima Puniani. 2021. "Post-Covid World Economy and India-China Bilateral Trade." Trade and Development Review 13 (2).

Olivia, Susan, John Gibson, and Rus' an Nasrudin. 2020. "Indonesia in the Time of Covid19." Bulletin of Indonesian Economic Studies 56 (2). Taylor \& Francis: 143-74.

Prabowo, Hadi, Wirman Syafri, and Juanda Juanda. 2020. "PANDEMIC AT THE POLLS: PREPAREMENT AND ARRANGEMENT OF INDONESIAN REGIONAL THE ELECTION IN THE MIDST OF COVID-19." International Journal of Management (IJM) 11 (12).

Prideaux, Bruce, Michelle Thompson, and Anja Pabel. 2020. “Lessons from COVID-19 Can Prepare Global Tourism for the Economic Transformation Needed to Combat Climate Change." Tourism Geographies 22 (3). Taylor \& Francis: 667-78.

Qarnain, Syed Shuibul, S Muthuvel, and S Bathrinath. 2020. "Review on Government Action Plans to Reduce Energy Consumption in Buildings amid COVID-19 Pandemic Outbreak." Materials Today: Proceedings. Elsevier.

Riadil, Ikrar Genidal. 2020. "Tourism Industry Crisis and Its Impacts: Investigating the Indonesian Tourism Employees Perspectives' in the Pandemic of COVID-19." Jurnal Kepariwisataan: Destinasi, Hospitalitas Dan Perjalanan 4 (2): 98-108.

Rizou, Myrto, Ioannis M Galanakis, Turki M S Aldawoud, and Charis M Galanakis. 2020. "Safety of Foods, Food Supply Chain and Environment within the COVID-19 Pandemic." Trends in Food Science \& Technology 102. Elsevier: 293-99.

Rosanti, Ratna. 2020. "Pandemic At the Polls: How To Prepare the Elections Post Covid19 (Towards Indonesia Local Elections in 2020)." Jurnal Academia Praja 3 (02): 147-67.

Salahudin, Achmad Nurmandi, Tri Sulistyaningsih, Muhammad Lutfi, and Iradhad Taqwa Sihidi. 2020. "Analysis of Government Official Twitters during Covid-19 Crisis in Indonesia." Journal of Talent Development and Excellence 12 (1): 3899-3915.

Setiati, Siti, and Muhammad Khifzhon Azwar. 2020. "COVID-19 and Indonesia." Acta Medica Indonesiana 52 (1): 84-89.

Subekti, Nanang, Ismi Dwi Astuti Nurhaeni, and Rina Herlina Hariyanti. 2020. "The Dynamic Capability of the Indonesian General Election Commission (KPU) in the 2020 Election during the COVID-19 Pandemic." In 6th International Conference on Social and Political Sciences (ICOSAPS 2020), 346-50. Atlantis Press.

Suryahadi, Asep, Ridho Al Izzati, and Daniel Suryadarma. 2020. "The Impact of COVID-19 Outbreak on Poverty: An Estimation for Indonesia." SMERU Working Paper.

Published by University of Airlangga.

This is an open access article under the CC BY SA license (https://creativecommons.org/licenses/by-sa/4.0/) 